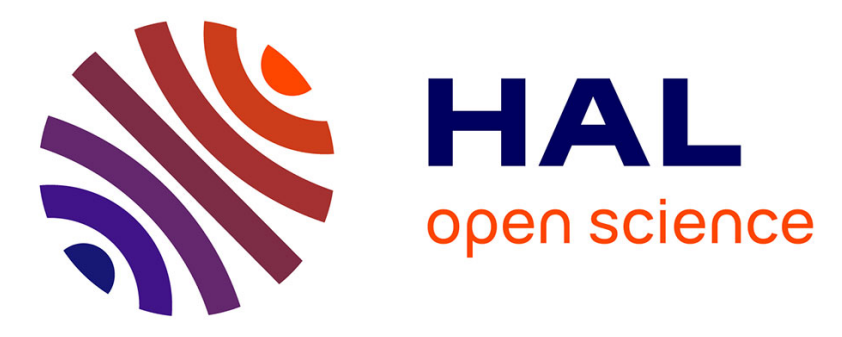

\title{
A Highly Stable Organic Radical Cation
}

Mathilde Berville, Jimmy Richard, Monika Stolar, Sylvie Choua, Nolwenn Le Breton, Christophe Gourlaouen, Corinne Boudon, Laurent Ruhlmann, Thomas Baumgartner, Jennifer Wytko, et al.

\section{- To cite this version:}

Mathilde Berville, Jimmy Richard, Monika Stolar, Sylvie Choua, Nolwenn Le Breton, et al.. A Highly Stable Organic Radical Cation. Organic Letters, 2018, 20 (24), pp.8004-8008. 10.1021/acs.orglett.8b03579 . hal-01993520

\section{HAL Id: hal-01993520 https://hal.science/hal-01993520}

Submitted on 24 Jan 2019

HAL is a multi-disciplinary open access archive for the deposit and dissemination of scientific research documents, whether they are published or not. The documents may come from teaching and research institutions in France or abroad, or from public or private research centers.
L'archive ouverte pluridisciplinaire HAL, est destinée au dépôt et à la diffusion de documents scientifiques de niveau recherche, publiés ou non, émanant des établissements d'enseignement et de recherche français ou étrangers, des laboratoires publics ou privés. 


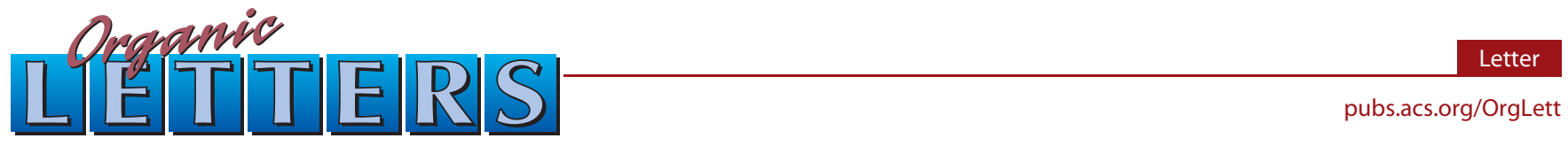

\title{
A Highly Stable Organic Radical Cation
}

\author{
2 Mathilde Berville, ${ }^{\dagger}$ Jimmy Richard, ${ }^{\dagger}$ Monika Stolar, ${ }^{\dagger}$ Sylvie Choua, ${ }^{\dagger}$ Nolwenn Le Breton, ${ }^{\dagger}$ \\ ${ }_{3}$ Christophe Gourlaouen, ${ }^{\dagger}$ Corinne Boudon, ${ }^{\dagger}$ Laurent Ruhlmann, ${ }^{\dagger}$ Thomas Baumgartner, ${ }^{\ddagger}$ \\ 4 Jennifer A. Wytko, ${ }^{* \dagger}{ }^{\dagger}$ and Jean Weiss ${ }^{* \dagger}$ \\ $5{ }^{\dagger}$ Institut de Chimie de Strasbourg, UMR 7177 Université de Strasbourg-CNRS, Institut LeBel, 4 rue Blaise Pascal, 67008 Strasbourg, \\ 6 France \\ $7{ }^{\star}$ Department of Chemistry, York University, 4700 Keele Street, Toronto, Ontario M3J 1P3, Canada
}

\section{S Supporting Information}

9 ABSTRACT: Functionalization of a methylviologen with four methyl

10 ester substituents significantly facilitates the first two reduction steps. The

11 easily generated radical cation showed markedly improved air stability

12 compared to the parent methylviologen, making this derivative of interest

13 in organic electronic applications.

"A mong the strong, organic-based electron acceptors, quaternized derivatives of $4,4^{\prime}$-bipyridine, also known as 16 viologens, are promising candidates for applications in organic 17 electronics, ${ }^{1}$ molecular machines, ${ }^{2}$ and as functional materials. ${ }^{3}$ 18 Interest in this family of acceptors stems from their simple 19 preparation, stability, and three, distinctly colored, redox 20 states. ${ }^{4}$ Stable organic acceptors for which the first reduction 21 potential is near $0 \mathrm{~V}$, or even positive, are highly desirable for 22 practical applications. ${ }^{2}$ Tuning the potential of viologen 23 derivatives is commonly achieved by changing the $\mathrm{N}$ 24 substituent (either alkyl or aryl) or the counteranions. ${ }^{5,6}$ 25 Another more effective strategy that significantly facilitates the 26 first reduction compared to that of methyl viologen $\left(\mathrm{MV}^{2+}\right)$ 27 utilizes the introduction of main-group element ${ }^{7-11}$ or 28 carbon $^{12}$ bridges between the pyridyl moieties of the viologen 29 framework. Few other reports describe the functionalization of 30 the viologen's carbon skeleton with electron-withdrawing 31 groups as a method to alter its electronic properties. ${ }^{13}$

32 Herein, we describe two remarkable features of a viologen $33\left(\mathbf{1}^{2+}\right)$ bearing methyl ester groups at the $2,2^{\prime}, 6,6^{\prime}$ positions. 34 Not only do these four electron-withdrawing groups 35 significantly facilitate both reduction potentials but they also 36 stabilize the radical cation in organic solution, even in the 37 presence of oxygen. Although viologen radical cations can be 38 stabilized as dimers under argon at low temperature ${ }^{4}$ or in 39 host-guest systems, ${ }^{14}$ and air-stable viologen radical cations 40 encapsulated in catenanes have been reported by Stoddart, ${ }^{15}$ 41 there are no other examples of simple viologen derivatives in a 42 stable radical-cation state.

43 The tetraester viologen $\mathbf{1}^{2+}$ was synthesized in three steps 44 starting from chelidamic acid ${ }^{16,17} \mathbf{2}$ (Scheme 1 ), which was 45 transformed to the methyl ester of the chloropyridine
Scheme 1. Synthesis of the Tetraester Viologen $1^{2+}$<smiles>O=C(O)c1cc(O)cc(C(=O)O)n1</smiles>

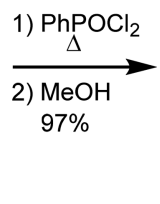<smiles>COC(=O)c1cc(Cl)cc(C(=O)OC)n1</smiles>

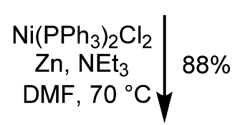<smiles></smiles>

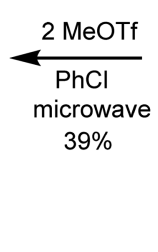

derivative 3 by subsequent treatment with $\mathrm{PhPOCl}_{2}$ and 46 $\mathrm{MeOH} .^{18}$ After optimization of the previously reported 47 coupling conditions by Oda et al., ${ }^{19}$ chloropyridine 348 underwent clean homocoupling that afforded bipyridine $\mathbf{4}$ in 49 $88 \%$ yield. Quaternization of the nitrogen atoms of the 50 bipyridine required harsh conditions, indicating the weak 51 nucleophilic character of the pyridine nitrogen atoms. 52 Treatment of 4 with methyl triflate (MeOTf) under microwave 53 irradiation afforded viologen $\mathbf{1}^{2+}$ as its triflate salt in $39 \%$ yield. 54

Received: November 8, 2018 
55 Single crystals of the dicationic species were obtained by 56 slow diffusion of $\mathrm{Et}_{2} \mathrm{O}$ in $\mathrm{MeCN}$. In the solid-state structure ${ }^{20}$ 57 of $\mathbf{1}^{2+}$ (Figure 1), the bipyridinium rings are twisted with a $32^{\circ}$

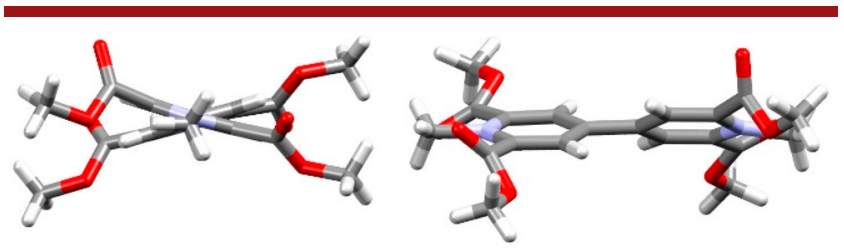

Figure 1. Side views of the viologen $\mathbf{1}^{2+}$ in the solid state. Triflate anions and solvent molecules have been omitted for clarity.

58 dihedral angle that is closer to the $36^{\circ}$ twist of $1,1^{\prime}$ 59 diphenylviologen ${ }^{21}$ than to the nearly coplanar structures 60 observed for most 1,1-dialkylviologen dications. The structure 61 of $1^{2+}$ also shows the possible formation of intramolecular 62 hydrogen bonds between the ester groups and the $\mathrm{N}$-methyl 63 substituents $(2.1-2.5 \AA)$ or the pyridine protons $(\sim 2.4 \AA)$ 64 (see Supporting Information).

65 The redox properties of $\mathbf{1}^{2+}$ were investigated by electro66 chemical methods. Cyclic voltammetry (CV) on a glassy 67 carbon electrode in $\mathrm{CH}_{3} \mathrm{CN}$ solutions with tetrabutylammo68 nium hexafluorophosphate $\left(\mathrm{TBAPF}_{6} ; 0.1 \mathrm{M}\right)$ as supporting 69 electrolyte showed three reversible reductions (Figure 2a). The 70 first two one-electron reductions at -0.27 and $-0.50 \mathrm{~V}$ versus $71 \mathrm{Fc}^{+} / \mathrm{Fc}$ are, respectively, attributed to the formation of the 72 radical cation $\mathbf{1}^{+}$and the neutral $\mathbf{1}^{0}$. The third reduction 73 detected from the $\mathrm{CV}$ at $-1.90 \mathrm{~V}$ versus $\mathrm{Fc}^{+} / \mathrm{Fc}$ is a two74 electron event that generates $\mathbf{1}^{2-}$. This reduction was almost 75 absent in rotating disk electrode experiments (Figure 2b), 76 suggesting that the neutral form $\left(1^{0}\right)$ undergoes a relatively 77 slow chemical reaction once formed. It is also possible that the 78 generated $\mathbf{1}^{2-}$ species is sparingly soluble in the $0.1 \mathrm{M} \mathrm{TBAPF}_{6}$ $79 \mathrm{CH}_{3} \mathrm{CN}$ medium. Controlled-potential coulometry at -0.37 80 and at $-0.60 \mathrm{~V}$ versus $\mathrm{Fc}^{+} / \mathrm{Fc}$ resulted in the respective 81 exchange of 0.97 and 1.85 electrons per molecule of compound 821.

83 The first two reductions of $\mathbf{1}^{2+}$ are shifted by +560 and +740 $84 \mathrm{mV}$, respectively, compared to those of $\mathrm{MV}^{2+}\left(E_{\text {red1,1/2 }}=-0.83\right.$ $85 \mathrm{~V}$ and $E_{\text {red2,1/2 }}=-1.24 \mathrm{~V}$ vs $\left.\mathrm{Fc}^{+} / \mathrm{Fc}\right)$ under the same 86 experimental conditions. The significantly less cathodic values of these potentials are attributed to the presence of the four 87 electron-withdrawing ester groups. When the same ester 88 groups are appended to an aryl ring at the quaternized 89 nitrogen atoms of a viologen, the electronic effects are less 90 pronounced ${ }^{6}$ than in $\mathbf{1}^{2+}$. Hence, conjugation effects also play a 91 role in tuning the redox properties, as supported by the small 92 contribution of the ester group in the density functional theory 93 (DFT)-generated singly occupied molecular orbital (SOMO) 94 (Figure 3 and Supporting Information).

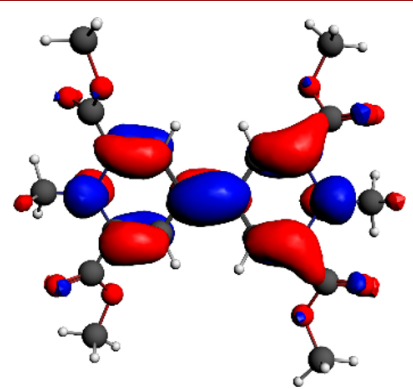

Figure 3. ADF view drawing of the Kohn-Sham SOMO of the radical cation $\mathbf{1}^{\mathbf{}^{+}}$.

The colorless divalent viologen $\mathbf{1}^{2+}$ mainly absorbs at 27896 $\mathrm{nm}$ (Figure 4, blue spectrum). Upon one-electron reduction, $97 \mathrm{f4}$ this absorbance decreases in intensity, while new absorption 98 bands grow at 334, 417, 769, and $852 \mathrm{~nm}$ (shoulder) for the 99 green radical cation $\mathbf{1}^{+}$(Figure 4, green spectrum and 100 Supporting Information). The absence of absorption bands 101 in the near-infrared (NIR) indicates that $\pi$-dimers do not 102 form $^{4}$ in solution at $1 \times 10^{-3} \mathrm{M}$ and suggests that the radical 103 cation is stabilized only by the four electron-withdrawing ester 104 groups. We attribute the broadness of the absorption centered 105 at $769 \mathrm{~nm}$ to the coexistence of several possible conformations 106 of the ester groups, as seen in DFT calculations, or to 107 vibrational states. $^{22}$ The second reduction generates a red, 108 neutral viologen species $\mathbf{1}^{0}$ that absorbs at $492 \mathrm{~nm}$ (Figure 4, 109 red spectrum). Aside from indicating the absence of $\pi$-dimer 110 formation, an interesting feature of the UV-vis-NIR 111 monitoring of the three species $\mathbf{1}^{2+}, \mathbf{1}^{\mathbf{}^{+}}$, and $\mathbf{1}^{\mathbf{0}}$ is their 112 individually addressable character and readability at specific 113 wavelengths. Reversible changes of the absorptions at 278, 417, 114
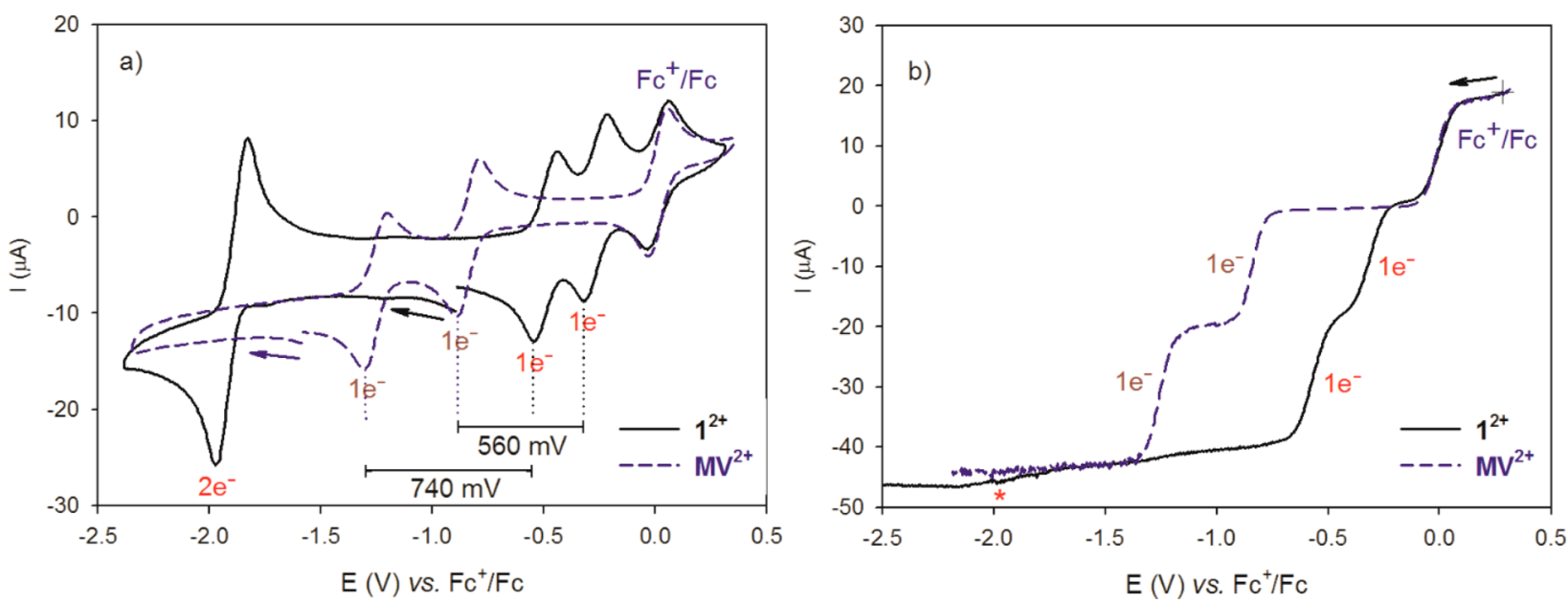

Figure 2. $\mathrm{CV}$ (a) and rotating disk electrode voltammetry (b) of $\mathbf{1}^{2+}$ and $\mathbf{M V}^{2+}$ in $\mathrm{CH}_{3} \mathrm{CN}+0.1 \mathrm{M} \mathrm{TBAPF}$ : working electrode $=$ glassy carbon, pseudoreference $=\mathrm{Pt}$, counter electrode $=\mathrm{Pt}$, internal reference $=\mathrm{Fc}$. (a) $v=0.1 \mathrm{~V} / \mathrm{s}$; (b) $v=0.02 \mathrm{~V} / \mathrm{s}$, rotation: $1000 \mathrm{rpm}$. 


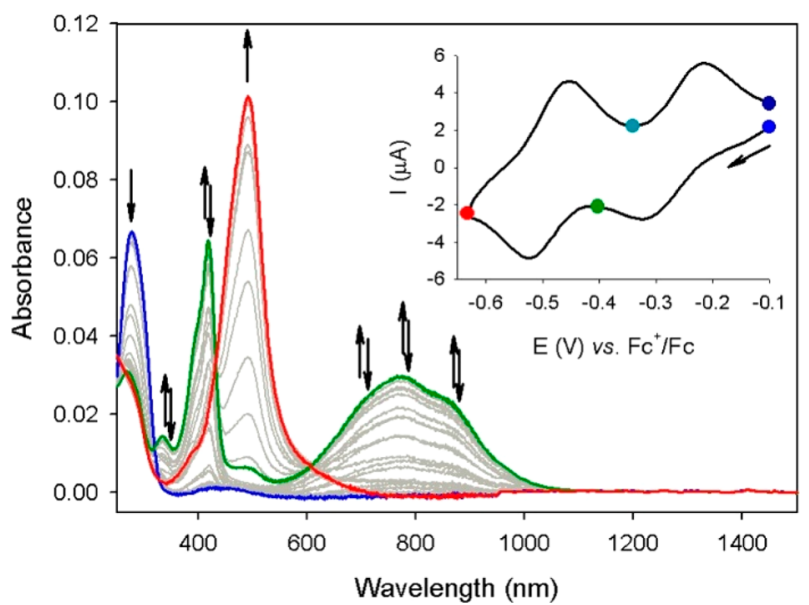

Figure 4. UV-Vis-NIR monitoring of the reduction of $\mathbf{1}^{2+}$. (inset) Corresponding $\mathrm{CV}$ at scan rate of $0.01 \mathrm{~V} \mathrm{~s}^{-1}$. Solution $\left(c=1 \times 10^{-3}\right.$ M) of $1^{2+}$ in $\mathrm{CH}_{3} \mathrm{CN}+0.1 \mathrm{M} \mathrm{TBAPF}_{6}$ recorded with an optically transparent thin-layer $(0.2 \mathrm{~mm})$ electrochemical cell equipped with an $\mathrm{Au}$ mini-grid $\mathrm{WE}$ and $\mathrm{CaF}_{2}$ optical windows, reference $\mathrm{AgCl} / \mathrm{Ag}$.

115492 , and $769 \mathrm{~nm}$ over several reduction-oxidation cycles 116 confirmed the reversibility of the redox interconversion 117 features of the three redox states (see Supporting Information). 118 Electron paramagnetic resonance (EPR) studies confirmed 119 the paramagnetic, radical character of $\mathbf{1}^{+}$. The reaction of $\mathbf{1}^{2+}$ 120 with 1 equiv of ascorbic acid yielded a well-resolved EPR 121 spectrum (Figure 5) centered at $g=2.0032$ corresponding to
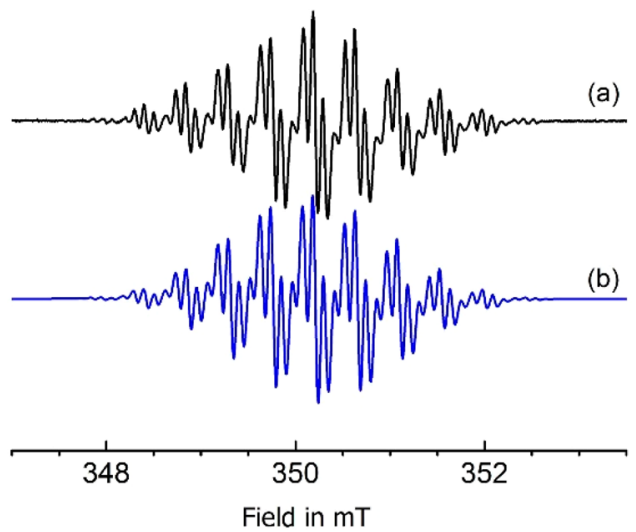

Figure 5. X-band EPR spectrum of $\mathbf{1}^{+}$(a) in $\mathrm{CH}_{3} \mathrm{CN}$ at $10^{-3} \mathrm{M}$ at room temperature; (b) simulated spectrum.

122 two sets of four and six equivalent protons $\left(A_{1}\left({ }^{1} \mathrm{H}\right)=0.11 \mathrm{mT}\right.$, $\left.123 A_{2}\left({ }^{1} \mathrm{H}\right)=0.43 \mathrm{mT}\right)$, respectively, and one set with two 124 equivalent nitrogen atoms $\left(A_{1}\left({ }^{14} \mathrm{~N}\right)=0.45 \mathrm{mT}\right)$. The same 125 spectrum was obtained by electrolysis. The colorless solution 126 turned green upon one-electron reduction to generate the 127 radical cation $\mathbf{1}^{+}$. After the second reduction, the solution 128 turned red, and the intensity of the EPR spectrum decreased 129 gradually to give the silent neutral species $\mathbf{1}^{0}$.

130 The air stability of the radical cation $\mathbf{1}^{+}$over time was also 131 investigated by EPR (Figure 6). After the radical cation was 132 generated by coulometry in $\mathrm{MeCN}$, samples of the solution of $133 \mathbf{1}^{\mathbf{0}^{+}}$were transferred to EPR tubes purged with argon or open 134 to air. The argon sample was stable for more than $40 \mathrm{~h}$. Even 135 after three months, the intensity of the EPR spectrum of the 136 same solution remained constant. For samples under air, the

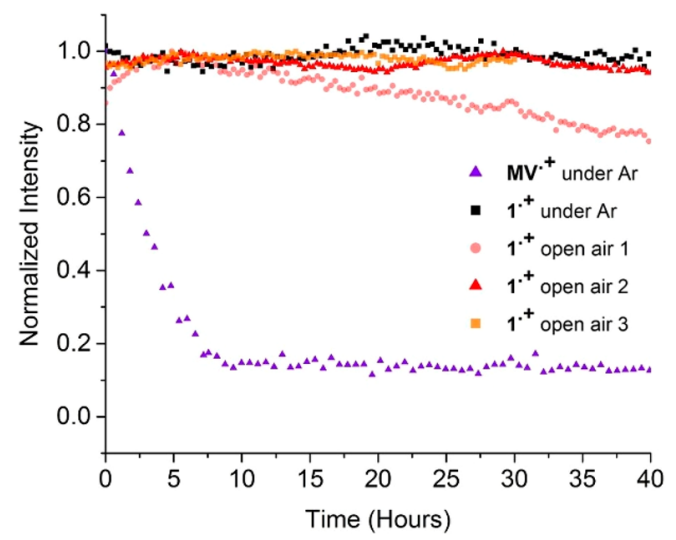

Figure 6. Double integrated EPR spectrum of $\mathbf{1}^{+}$and $\mathrm{MV}^{+}$in $\mathrm{CH}_{3} \mathrm{CN}$ at $1 \times 10^{-3} \mathrm{M}$ at room temperature under $\mathrm{Ar}$ and open to air.

intensity of the EPR signal of $\mathbf{1}^{\mathbf{0}^{+}}$remained relatively stable 137 over $40 \mathrm{~h}$ in two cases. In the third case (Figure $6, \mathbf{1}^{{ }^{+}}$open air 138 3 ), the intensity of the EPR signal increased initially over the 139 first $5 \mathrm{~h}$ and then decreased by $\sim 25 \%$ after $40 \mathrm{~h}$. We assign the 140 initial increase to the presence of some diamagnetic dimeric 141 species $\left(\mathbf{1}^{+}\right)_{2}$ that dissociate into paramagnetic $\mathbf{1}^{{ }^{+}}$monomers 142 within the first few hours. The presence of oxygen in the 143 samples exposed to air was confirmed by a broad EPR signal 144 (see Supporting Information). Under the same experimental 145 conditions, the $\mathrm{MV}^{+}$reference compound was considerably 146 less stable under argon, as demonstrated by the rapid decay ${ }^{23} 147$ of the EPR signal within a few hours (Figure 6). In the 148 presence of air, $\mathrm{MV}^{+}{ }^{+}$was very unstable, and no EPR signal was 149 observed. Together, these data confirmed the high stability of 150 $1^{+}$.

Despite the stability of the radical cation, we were unable to 152 grow single crystals of sufficient quality for X-ray diffraction. 153 Thus, optimizations of the geometries of $\mathbf{1}^{2+}$ and $\mathbf{1}^{\mathbf{0}^{+}}$were 154 performed without any symmetry restriction. For the dication 155 $\mathbf{1}^{2+}$, the twist between the pyridinium rings was reproduced 156 $\left(33^{\circ}\right.$ vs $\left.32^{\circ}\right)$, and the accord between experimental and 157 calculated geometry remained quite satisfactory. A large 158 highest occupied molecular orbital-lowest unoccupied molec- 159 ular orbital (HOMO-LUMO) energy gap was calculated 160 $(4.60 \mathrm{eV})$ for $\mathbf{1}^{2+}$, but the LUMO was stabilized by $0.7 \mathrm{eV} 161$ compared to $\mathrm{MV}^{2+}$. These calculations corroborate with the 162 electrochemical data.

When the dication $\mathbf{1}^{2+}$ is reduced to $\mathbf{1}^{+}$, the optimized 164 geometrical parameters provide a more planar structure with a 165 value of dihedral angle of $15^{\circ}$. This twist is higher than the $6^{\circ} 166$ and $11^{\circ}$ observed in the two independent molecules of the X- 167 ray structure of $\mathrm{MV}^{+} \cdot{ }^{24}$ Comparison of these data suggests less 168 electronic delocalization in $\mathbf{1}^{+}$than in $\mathrm{MV}^{+}$. The calculated 169 ${ }^{1} \mathrm{H}$ and ${ }^{14} \mathrm{~N}$ isotropic constants (see Supporting Information) 170 are in close agreement with the experimental values. As shown 171 by the SOMO illustrated in Figure 3, the unpaired electron is 172 essentially localized on the pyridine rings, on both N-methyl 173 groups, and only slightly on the tetraester substituents. This 174 observation supports the stabilizing effect of the four electron- 175 withdrawing ester groups on the radical cation. 176

In conclusion, the tetraester derivative of methylviologen is a 177 strong electron acceptor that converts easily and reversibly into 178 its radical cation species. Because of the electron-attracting 179 effect of the ester groups, the radical species is stable for 180 months under argon and for hours in the presence of oxygen. 181 
182 These features are of great interest from the perspective of air183 operating electrochromic devices and molecular switches. 184 Isolation and investigations of $\mathbf{1}^{+}$as a solid material are in 185 progress.

\section{ASSOCIATED CONTENT \\ 187 S Supporting Information}

188 The Supporting Information is available free of charge on the 189 ACS Publications website at DOI: 10.1021/acs.or190 glett.8b03579.

191 Experimental procedures, spectro-electrochemical and 192 EPR spectra, hyperfine coupling constants, calculated 193 molecular orbitals, X-ray crystal data (PDF)

\section{Accession Codes}

195 CCDC 1846774 contains the supplementary crystallographic 196 data for this paper. These data can be obtained free of charge 197 via www.ccdc.cam.ac.uk/data request/cif, or by emailing 198 data_request@ccdc.cam.ac.uk, or by contacting The Cam199 bridge Crystallographic Data Centre, 12 Union Road, 200 Cambridge CB2 1EZ, UK; fax: +44 1223336033.

\section{AUTHOR INFORMATION}

\section{Corresponding Authors}

203 *E-mail: jweiss@unistra.fr. (J.A.W.)

204 *E-mail: jweiss@unistra.fr. (J.W.)

205 ORCID ${ }^{\circ}$

206 Thomas Baumgartner: 0000-0001-8066-0559

207 Jennifer A. Wytko: 0000-0001-5370-4253

\section{Author Contributions}

209 All authors have approved the final version of the manuscript. 210 Notes

211 The authors declare no competing financial interest.

\section{$212 \square$ ACKNOWLEDGMENTS}

213 The authors thank the "Agence National de la Recherche" 214 (ANR-12-BS07-0014-01), the CNRS, and the Univ. of 215 Strasbourg for funding and C. Bailly for the structure 216 determination. T.B. thanks the Canada Research Chairs 217 program for financial support. S.C. and N.L.B. thank REseau 218 NAtional de Rpe interDisciplinaire, RENARD, Fédération IR219 RPE CNRS 3443.

\section{REFERENCES}

221 (1) (a) Stolar, M.; Baumgartner, T. Organic n-type materials for 222 charge transport and charge storage applications. Phys. Chem. Chem. 223 Phys. 2013, 15, 9007. (b) Eftaiha, A. F.; Sun, J.-P.; Hill, I. G.; Welch, 224 G. C. Recent advances of non-fullerene, small molecular acceptors for 225 solution processed bulk heterojunction solar cells. J. Mater. Chem. A 226 2014, 2, 1201.

227 (2) Wang, Y.; Frasconi, M.; Stoddart, F. J. Introducing Stable 228 Radicals into Molecular Machines. ACS Cent. Sci. 2017, 3, 927.

229 (3) Striepe, L.; Baumgartner, T. Viologens and Their Application as 230 Functional Materials. Chem. - Eur. J. 2017, 23, 16924.

231 (4) Kosower, E. M.; Cotter, J. L. Stable Free Radicals. II. The 232 Reduction of 1-Methyl-4-cyanopyridinium Ion to Methylviologen 233 Cation Radical. J. Am. Chem. Soc. 1964, 86, 5524.

234 (5) (a) Hünig, S.; Schenk, W. Über zweistufige Redoxsysteme, 235 XXVI. Einfluß von $\mathrm{N}$-Substituenten in 4,4'-Bipyridylen auf das 236 Redoxverhalten, die Radikalstabilität und die Elektronenspektren. 237 Liebigs, Ann. Chem. 1979, 1979, 1523. (b) Bird, C. L.; Kuhn, A. T. 238 Electrochemistry of the viologens. Chem. Soc. Rev. 1981, 10, 49. (c) Porter, W. W., III; Vaid, T. P.; Rheingold, A. L. Synthesis and 239 Characterization of a Highly Reducing Neutral "Extended Viologen" 240 and the Isostructural Hydrocarbon 4,4"“-Di- $n$-octyl-p-quaterphenyl. J. 241 Am. Chem. Soc. 2005, 127, 16559. (d) Wang, Y.; Xu, S.; Gao, F.; 242 Chen, Q.; Ni, B.-B.; Ma, Y. Fast naked-eye detection of amines with 243 viologen derivatives. Supramol. Chem. 2013, 25, 344. (e) Jordão, N.; 244 Cabrita, L.; Pina, F.; Branco, L. C. Novel Bipyridinium Ionic Liquids 245 as Liquid Electrochromic Devices. Chem. - Eur. J. 2014, 20, 3982. 246 (f) Chen, L.; Hartl, F.; Colquhoun, H. M.; Greenland, B. W. 247 Prediction of cathodic $\mathrm{E}_{1 / 2}{ }^{1}$ and $\mathrm{E}_{1 / 2}{ }^{2}$ values for viologen-containing 248 conjugated unimers and dimers from calculated $\mathrm{pK}_{\mathrm{b}}$ values of the 249 aromatic substituents. Tetrahedron Lett. 2017, 58, 1859.

(6) Chen, L.; Willcock, H.; Wedge, C. J.; Hartl, F.; Colquhoun, H. 251 M.; Greenland, B. W. Efficient access to conjugated 4,4'-bipyridinium 252 oligomers using the Zincke reaction: synthesis, spectroscopic and 253 electrochemical properties. Org. Biomol. Chem. 2016, 14, 980. (7) Attalla, M. I.; Summers, L. A. Synthesis of thieno[2,3-c:5,4- 255 c]dipyridine and the one electron transfer properties of its dimethyl 256 diquaternary salt. J. Heterocycl. Chem. 1985, 22, 751.

257

(8) Durben, S.; Baumgartner, T. 3,7-Diazadibenzophosphole Oxide: 258 A Phosphorus-Bridged Viologen Analogue with Significantly Lowered 259 Reduction Threshold. Angew. Chem., Int. Ed. 2011, 50, 7948.

(9) (a) Benniston, A. C.; Hagon, J.; He, X.; Yang, S.; Harrington, R. 261 W. Spring Open Two-plus-Two Electron Storage in a Disulfide- 262 Strapped Methyl Viologen Derivative. Org. Lett. 2012, 14, 506. (b) Li, 263 G.; Zhang, W.; Zhou, K.; Ding, Y.; Liu, F.; He, X.; He, G.; et al. 264 Narrow-Bandgap Chalcogenoviologens for Electrochromism and 265 Visible-Light-Driven Hydrogen Evolution. Angew. Chem., Int. Ed. 266 2018, 57, 4897.

267

(10) (a) Stolar, M.; Borau-Garcia, J.; Toonen, M.; Baumgartner, T. 268 Synthesis and Tunability of Highly Electron-Accepting, N-Benzylated 269 "Phosphaviologens. J. Am. Chem. Soc. 2015, 137, 3366. (b) Stolar, M.; 270 Baumgartner, T. Functional conjugated pyridines via main-group 271 element tuning. Chem. Commun. 2018, 54, 3311. (11) Greulich, T. W.; Yamaguchi, E.; Doerenkamp, C.; Lübbes- 273 meyer, M.; Daniliuc, C. G.; Fukazawa, A.; Eckert, H.; Yamaguchi, S.; 274 Studer, A. Synthesis and Physical Properties of Strained Doubly 275 Phosphorus-Bridged Biaryls and Viologens. Chem. - Eur. J. 2017, 23, 276 6029.

(12) Yang, Y.; Liu, D.; Song, M.; Shi, D.; Liu, B.; Cheng, K.; Lu, Y.; 278 Liu, H.; Yang, M.; Wang, W.; Li, J.; Wei, J. Facile Synthesis of $\pi$ - 279 Extended Viologens: Electron-Deficient Polycyclic Aza-aromatics. 280 Chem. - Eur. J. 2017, 23, 7409.

281

(13) (a) Fielden, R.; Summers, L. A. The 2,2'-dicyano-1,1'- 282 dimethyl-4,4'-bipyridylium di-cation: A viologen indicator with a 283 high redox potential. Experientia 1974, 30, 843. (b) Kuzuya, M.; 284 Kondo, S.; Murase, K. A novel single electron transfer in solid-state 285 organic compounds: mechanically induced reduction of dipyridinium 286 salts. J. Phys. Chem. 1993, 97, 7800. (c) Geraskina, M. R.; Dutton, A. 287 S.; Juetten, M. J.; Wood, S. A.; Winter, A. H. The Viologen Cation 288 Radical Pimer: A Case of Dispersion-Driven Bonding. Angew. Chem., 289 Int. Ed. 2017, 56, 9435.

290

(14) (a) Lee, J. W.; Samal, S.; Selvapalam, N.; Kim, H.-J.; Kim, K. 291 Cucurbituril Homologues and Derivatives: New Opportunities in 292 Supramolecular Chemistry. Acc. Chem. Res. 2003, 36, 621. (b) Zhang, 293 D.-W.; Tian, J.; Chen, L.; Zhang, L.; Li, Z.-T. Dimerization of 294 Conjugated Radical Cations: An Emerging Non-Covalent Interaction 295 for Self-Assembly. Chem. - Asian J. 2015, 10, 56 and referenced 296 therein. .

(15) (a) Barnes, J. C.; Fahrenbach, A. C.; Cao, D.; Dyar, S. M.; 298 Frasconi, M.; Giesener, M. A.; Benítez, D.; Tkatchouk, E.; 299 Chernyashevskyy, O.; Shin, W. H.; Li, H.; Sampath, S.; Stern, C. 300 L.; Sarjeant, A. A.; Hartlieb, K. J.; Liu, Z.; Carmieli, R.; Botros, Y. Y.; 301 Choi, J. W.; Slawin, A. M. Z.; Ketterson, J. B.; Wasielewski, M. R.; 302 Goddard, W. A., III; Stoddart, J. F. A Radically Configurable Six-State 303 Compound. Science 2013, 339, 429. (b) Sun, J.; Liu, Z.; Liu, W.-G.; 304 Wu, Y.; Wang, Y.; Barnes, J. C.; Hermann, K. R.; Goddard, W. A., III; 305 Wasielewski, M. R.; Stoddart, J. F. Mechanical-Bond-Protected, Air- 306 Stable Radicals. J. Am. Chem. Soc. 2017, 139, 12704. 
308 (16) Riegel, R.; Zwilgmeyer, F. Chelidonic Acid. Org. Synth. 1937, 30917,40 .

310 (17) Howath, G.; Rusa, C.; Kontos, Z.; Gerencsér, J.; Huszthy, P. A 311 new Efficient Method for the Preparation of 2,6-Pyridinedimethyl 312 Ditosylates from Dimethyl 2,6-Pyridinedicarboxylates. Synth. Com313 mun. 1999, 29, 3719.

314 (18) Lamture, J. B.; Zhou, Z. H.; Kumar, A. S.; Wensel, T. G. 315 Luminescence Properties of Terbium(III) Complexes with 4316 Substituted Dipicolinic Acid Analogs. Inorg. Chem. 1995, 34, 864.

317 (19) Iyoda, M.; Otsuka, H.; Sato, K.; Nisato, N.; Oda, M. 318 Homocoupling of Aryl Halides Using Nickel(II) Complex and Zinc 319 in the Presence of $\mathrm{Et}_{4} \mathrm{NI}$. An Efficient Method for the Synthesis of 320 Biaryls and Bipyridines. Bull. Chem. Soc. Jpn. 1990, 63, 80.

321 (20) CCDC 1846774. See Supporting Information for crystal data. 322 (21) Porter, W. W., III; Vaid, T. P. Isolation and Characterization of 323 Phenyl Viologen as a Radical Cation and Neutral Molecule. J. Org. 324 Chem. 2005, 70, 5028.

325 (22) Peon, J.; Tan, X.; Hoerner, J. D.; Xia, C.; Luk, Y. F.; Kohler, B. 326 Excited State Dynamics of Methyl Viologen. Ultrafast Photoreduction 327 in Methanol and Fluorescence in Acetonitrile. J. Phys. Chem. A 2001, $328105,5768$.

329 (23) Although all kinetic experimental decays for $\mathrm{MV}^{+}{ }^{+}$showed the 330 same trend, small variations were observed depending on the amount 331 of residual oxygen in solution.

332 (24) Bockman, T. M.; Kochi, J. K. Isolation and oxidation-reduction 333 of methylviologen cation radicals. Novel disproportionation in charge334 transfer salts by X-ray crystallography. J. Org. Chem. 1990, 55, 4. 